\title{
Deterritorialization and Poetic Form - Brazilian Contemporary Poetry and Urban Experience
}

(C) Flora Süssekind (translated by Marise Barros)

\section{E-mail - fsussekind@uol.com.br}

\section{Reterritorializations/Deterritorializations}

Brazilian literary imagination has been predominantly urban over the last decades. This is evident in reports with strong regional content, such as those by Raimundo Carrero, in stories about migration or difficulties in social adaptation, as in Marilene Felinto's As Mulheres de Tijucopapo (The Women of Tijucopapo), or where traces of the rural experience, such as in Angu de Sangue (Blood Cornmeal) by Marcelino Freire, are sometimes juxtaposed with everyday urban life. This dominance seems to point to the fact that Brazil's population has become mainly urban in this period, with only $30 \%$ remaining in the countryside, as well as to the reconfiguration of tensions between localism and cosmopolitanism, the rural and the urban. These are fundamental aspects for local cultural self-awareness that are increasingly marked by the hypertrophy of one of the poles, by the unfolding of mediations between the urban social organization and the artistic form, where duplication and representability do not necessarily mean an increase in the complexity of formal processes, of literary practice, and of the recent historical experience. Therefore, this growing complexity often results not exactly from explicit, documented representations of the urban, but rather from the production of nonrepresentational spaces and liminal, ambivalent, transitional zones of subjectivity.

Thus I have opted, in this work, to examine poetical production rather than, for example, rap or funk lyrics, which register the violent and excluding elements of everyday life in the outskirts of large Brazilian cities; or recent prose, marked by direct accounts, such as the novel Capão Pecado (Sin Capão), which was purposely written in ghetto language, with autobiographical material, by Férrez, a former baker, son of a bus-driver, dweller of the neighborhood Capão Redondo in São Paulo's south zone; or such as the prisoners' stories which have been compiled into the volume Letras de Liberdade (Letters of Freedom). This is a kind of testimonial prose also containing street memories, such as the book Por que não dancei (Why I Didn't Dance), written by a former homeless girl, Esmeralda do Carmo Ortiz; or homoerotic itineraries, such as those by José Carlos Honório; and dominated by a neo-documentary work that has been intensified in Brazilian contemporary fiction. A fiction that is sometimes marked by a 
kind of overlapping of the ethnographic and the fictional - of which both the novel Cidade de Deus (City of God) by Paulo Lins and the group of accounts and fragments of everyday street-life that make up Vozes do Meio-Fio (Curb Voices), by anthropologists Hélio R. S. Silva and Cláudia Milito, are good examples-and other times marked by a double record, where photos and accounts are mirrored, giving place to a succession of illustrated books which would almost become a genre pattern of this representational imposition.

This is what happens in Capão Pecado (Sin Capão), where the narrative is accompanied by two sets of professional and amateur photos that seem to materialize the Romanesque geography. Estação Carandiru (Carandiru Station) is an account by Dráuzio Varella of his voluntary work as a doctor in a São Paulo Prison, to which he added a vast pictorial archive taken from his private property, private collections, and newspaper files by way of a supplement, lending the report a photojournalistic referendum. This is also what happens, though in a different way, in Marcelino Freire's Angu de Sangue (Blood Cornmeal), where the purposely 'derealized' photographic images nevertheless perform an illustrative function, or in Treze (Thirteen), by Nelson de Oliveira, illustrated with photos extracted from the admissions file of a Victorian English asylum. In these books the grotesque aspect of the images serves equally to perversely reduplicate the unusual, yet ordinary, urban scenes and types in these tales.

The reiterated mutual mirroring movement between account and illustration generally functions in these illustrated books as a presentification expedient, as a production of evidence by means of shifting the reader's attention from the narrative process towards the context, towards the extra-literary referent of these accounts and fictions. But, as they seem to capture the urban referent with documentation and frequently bring it closer to the reader, when these images are observed, we find that they operate as clichés, reimpressions of a predictable repertoire of types and situations that (contrary to what they seem at first sight) stress social distinctions already fixed in everyday life. The broadening of the area of visibility may partly correspond, in these cases, to a re-statement of the distance between observer and documented matter, to restriction and immobilization of the historical perspective, to a conservative movement of reterritorialization.

This does not happen in Treze (Thirteen), where the mere fact of resorting to a Victorian photographic/hospital file already produces tension between this anachronistic photographic image and present storytelling. Nor does it happen in Minha História Dele ("My History of 
Him"), another illustrated text, by Valêncio Xavier, published in the first issue of the magazine Ficções (Fictions). There, only four images of a Korean man are available, a street-dweller of Curitiba who, as a sandwich-board man, carries his own story handwritten and hanging on his body. In this case, the re-duplication between text and image seems to reach such an extreme that even the account and the handwriting used for it are elements extracted from the posters hanging on the city wanderer's body-the account itself apparently being inscribed in the photos. The alternation between proximity and distance-noticeable in the internal contrast of each of the two pairs of almost identical photos, which constitute the tale-makes the beggar's observation temporal and points out, by means of the pronominal ironic play on words ("My History of Him") in the title, the link between the observer and the homeless man.

Valêncio Xavier's story gets closer, in this sense, to one of the most expanding topoi in Brazilian urban imaginary-that of the "chance encounter" between disparate people, defined by Ismail Xavier as "isolated experiences, marked by a certain singularity," offered by "migration" or by the "city space" [1]. It would seem that such experiences also have recent cinematographic examples, as the critic from São Paulo points out, in the fictional meeting between Sarah Bernhardt and three 'hillbillies' from the interior of Minas Gerais in "Amélia" by Ana Carolina; between Josué and a former teacher, Dora, in Central do Brasil (Central Station) by Walter Salles Jr.; between poor boys who, by chance, are armed, and an American man and his family in Como nascem os anjos (How Angels Are Born), by Muirlo Salles; between a fugitive prisoner and a middle-class young lady on New Year's Eve in O primeiro dia (Midnight), by Walter Salles and Daniela Thomas.

These meetings, in a dialogue with Baudelairean urban pictures, also manifest themselves in Brazilian contemporary poetry. For example, in "Spiritus ubi vult spirat," by Sebastião Uchoa Leite, the subject is crossing President Vargas Avenue when he comes across a "survivor" whose skirt is raised, while all the other people pass by indifferently. Also, in "031197," by Régis Bovincino, it says, "He could suddenly have drawn out the knife, on the sidewalk, they say," when referring to a street dweller. "Em sua cidade" ("In your town"), by Duda Machado, where, in the middle of the Bahian landscape, boys and beggars circulate among vendors and fruit baskets. Meanwhile, from the perspective of the speaking subject, "an intimate device, / destined to annul/ all presence, / intercepted the contact/ and retracted it, while tender, / to the root of the panic." 
But if from retreat we go to breathing, as in Duda Machado's poem, to a "return to oneself" that "re-erected the world" "beyond any attempt/ to escape or dominate," while going back to the short story "Minha História Dele" ("My Story of Him") by Valêncio Xavier, then the extreme realism of the photos -as well as their reduplication and the fact that part of the text is presented on the boards hanging on the beggar's body-, function as an almost immediate expedient for removing perspective, for transiting-and not for separation- between subject and object, between the invisible narrator and the photographic image of a street dweller. This effectively erases both the possibility of the subject retreating and of a merely illustrative relationship between text and photo, since it is the very succession of images (including those containing text) that produces the conflicting, uncomfortable narrative, set in action by the meeting with the homeless man, by the visual cut-outs and additions imposed on the board-text that covers him, and by the exercises of moving away and getting closer to this urban picture. Unlike the experience of segregation that dominates everyday city life, the implicit violence in this urban picture would then seem to result in a kind of unfolding of the visual intake, producing a double perspective of the account. For, in this case, the homeless man also seems to observe his text observer, besides the fact that the raw reproduction of his handwritten board also materially grants him a narrative function. This device would become structural also in João Gilberto Noll's work, where the narrators, invariably wandering and homeless, fictionally re-portray the urban experience of the homeless and their multiple strategies for surviving in the streets. The title of one of his novels involves, not by chance, a type of erratic narratorial auto-classification as a "quiet animal of the corner" (quieto animal da esquina).

Nevertheless, what is habitual in this illustrated urban literature is not the unfolding of perspective but rather the criminal-pathological cataloguing of places and human types (which is ridiculed in the collection of physiognomies in Thirteen), the fear of social heterogeneity, the reiterated criminalization of social divisions, and the reinforcement of a kind of endemic urban paranoia. The middle classes and financial elite respond by imposing self-segregation in the form of residential enclaves, shopping centers, business centers with, oftentimes controlled attendance, with investment in private security, bodyguards, night watchmen, alarms, fencing, and the privatization of streets and squares. This partly explains the popularization, in tune with this generalized insecurity, of crime stories and detective thrillers in Brazil between 1980 and 1990, such as the fiction of Rubem Fonseca. 
An imaginary representation of fear and violence is what fundamentally organizes the dominant urban landscape of Brazilian contemporary literature. That can be partly explained as a direct relation to the rise in the rate of violent crime in the country's large cities from 1980 to 1990, with the strengthening of organized crime, the inefficiency of the police force and of the legal system in enforcing public safety and justice, the growing visibility of the population contingent in absolute poverty that wanders through big cities, expelled from both the slums and from the fortified middle class enclaves, and a kind of generalized violence, reaching from traffic to family relationships, from football stadiums to professional killers, and to private security and vengeance activities. This sometimes brings detective fiction closer to "discourses of fear", to the proliferation of "speeches of the crime" [2]-both expressions used by Teresa Caldeira in Cidade de Muros (City of Walls), a study on "crime, segregation and citizenship in São Paulo." These "discourses" reorganize symbolically not only urban panic but also, in an equal measure, the fear of losing social status and property, financial instability, internal dilemmas, and structural social issues of Brazilian society. This criminalization of the social relations became more marked precisely during the period of political redemocratization in the country. This movement appears to function discursively by means of rigid classifications, stereotypes, and segregation, and is recurrent not only in crime-related news stories and individual stories of muggings and different forms of violence and homicide, but also in the literary production of recent decades. This literary production reterritorializes, with well-known criminal vocabulary, "a new pattern for organizing social differences in urban space," [3] a destabilizing process of social change that affects the dominant relations of power and the exercise of citizenship.

The urban thematizations of the country's recent cultural production are not limited, however, to literary workings of ethnographic or criminal reterritorialization. Some disfiguration and deterritorialization processes, which are structural to Brazilian contemporary poetry, function as particularly critical interlocutors of an urban experience of violence, instability and segregation. And it is these processes that will be examined next.

This does not mean, of course, that disfiguration is the only path to a critical dialog between literary form and urban experience in contemporary Brazil. It is enough to remember, in this sense, as a counter-example, the book Sob a Noite Física (Under the Physical Night) by Carlito Azevedo. In this case, one urban image in particularthat of garbage scattered around Rio de Janeiro-turns into a privileged sign for the reader. The initial poem of the book announces "the last flight of the blowfly" from "the garbage on the corner," and runs it 
through the initial texts of almost all sections, with their references to "garbage dump," "the garbage bin in the corner," garbage bins that, in the "convulsed pitch-black" look like indistinct shapes, and the "pain in the glimpse of a dream" which "with its speck of dirt, infiltrates" into the body. Transforming itself from external to internal, the garbage (which is in fact an aspect of the city's physical space) almost turns into an inhabitant, an animated shape and a constituent element of the lyrical self, producing an incorporation through which an aspect of the nocturnal landscape lends painful physical materialization to the embodiment of the subject. In the case of Carlito Azevedo's 1996 book, thematization of the urban is employed in these images of the garbage via proximity and via incorporation. However, this movement seems to point simultaneously to an itching-a painful corporeal experience that is close to disfiguration mechanisms-and to bloody exposure of the bodies. These are means by which the subjectivity in Brazilian cultural production (especially since the 1980s) has been constituted, frequently by means of horror.

\section{Guignol}

It is in fact not difficult to notice a trace of the Guignol in Brazilian cultural life in the last few decades: from the detailed descriptions of the corpses and murders of women in Acqua Toffana by Patrícia Melo, to the exhumation of the corpses of father and brother reported in the short story "A Carne e os Ossos" ("The Flesh and the Bones") from the book $O$ Buraco na Parede (The Hole in the Wall) by Rubem Fonseca; from the exposure of a child's corpse pierced by a wooden stake in one of the photographs by C. A. Silva exhibited in FUNARTE's Gallery in 1996, to "the homeless girl killed naked" in the report, full of portraits and police registers, by Valêncio Xavier; also the "teeth of putrefaction" that "swallow the body" in one of the poems from Cheiro Forte (Strong Smell) by Silviano Santiago; or the voracious living in the poem "Os Vivos" ("The Living") by Ferreira Gullar, where "ferocious gluttons...devour the other living beings" and "even the dead eat/ fleshes bones voices;" from the amputated leg of the narrator in the novel Hotel Atlântico (Hotel Atlantic) by João Gilberto Noll; to the subject-"all wired up"- stuck in a hospital bed in the section "Incertezas" ("Uncertainties") from the book Ficção Vida (Fiction Life) by Sebastião Uchoa Leite.

Guignolesque reference is also particularly stressed and seemingly methodical in recent theatrical production: from O Livro de Jó (The Book of Job) by Antônio Araújo and As Bacantes (The Bacchante) by José Celso Martinez Correia, to the descriptions and exposures of torture that constitute Bugiaria (Monkeyshines) by Moacir Chaves, and to Gerald Thomas's shows in general. Nowhere Man, for example, 
starts with its "Faust" wearing rather bloodstained clothes, with a female pseudo-cadaver as interlocutor. And, in his second production of Quartet by Heine Müller, the two characters, also with bloodstained clothes and knives, walk around amidst huge pieces of suspended meat and a backdrop with blood dripping everywhere-a horror component that has regularly been present in his theatre. Remember the body parts scattered on the floor in Matogrosso, or the heart and head pulled out of the female figures in The Flash and Crash Days.

However, what seems to have happened in some of the most recent Gerald Thomas productions is an increase in emphasis on these signs of blood, mutilation, and physical torment, accompanied by his own ironic explanation that he is working, much of the time, with some of the most characteristic tricks of the "Grand Guignol" genre: knives with retractable tips, tables that hide corpses, color nuances to variations of composition and texture of the fictitious blood, the loose head of the actress Fernanda Torres, pulled out from her body in The Flash and Crash Days and in O Império de Meias Verdades (The Empire of Half Truths), or to bodies riddled with arrows (such as Fernanda Montenegro's) and large knives (as in the opening of Nowhere Man).

If the theatre of Grand Guignol, hugely popular from the end of the nineteenth century until the period between the World Wars, anchored its scenic effect to the medical or criminal fait divers and to a mixture of interpretation and skillful exercise of magic, what seems to make it specially curious is, on the one hand, its transformation of technical innovations (lighting tricks, sound effects for telephones, automobiles, and medical novelties) into dramatic elements. On the other hand, its presentation of a kind of horror pastiche of not only the modern experience of the body and of subjectivity itself as unstable and fragmented, but above all of the figuration of the body as "body in pieces," which is dominant (though with variations of meaning) in modern and postmodern art. In this sense, in recent Brazilian Guignol, there is undoubtedly a dialog that involves extreme cruelty to the body present in some examples of contemporary body art, a dialog with tormented figuration, the paradigmatic and multivalent fragmentation in artistic production of the twentieth century, present in the mouths of Bruce Nauman or Francis Bacon, the huge eyes, pieces of legs, hands and several dismemberments employed by Louise Bourgeois, the photographs of corpse fragments by Andres Serrano, or the corporeal suppressions in the work of Beckett.

However, there may be other sources, not exclusively plastic, for this trace of the guignol. And some of them might be suggested, as in the theatre of "Grand Guignol" itself, by a mere reference to the country's journalism at the end of the 1990s, for instance: the succession of 
photographs of bones and corpses, file images of old portraits of leftist militants killed by the military police; and of the Brazilian politicians gone missing during military authoritarianism, which invaded the newspapers at the end of the 1990s thanks to new information having been brought to light; to the discovery of bones, and to the lawsuits filed by families involved in the identification of their dead. However, alongside this political picture file from the period of military dictatorship in the country, it is not difficult to notice a nearexacerbation of everyday life that is marked by the banalization of violence, by brutalization exposed daily on the crime pages of the Brazilian press and exposed with intensified repercussions. Such is the case of slaughters perpetrated by the police force, like the eleven youths killed in Acari, Baixada Fluminense, Rio de Janeiro, in 1990; the ten adolescents murdered in Morro de São Carlos in 1992; the massacre of 111 inmates of the Carandiru prison, São Paulo, in the same year; the executions of 21 people in Vigário Geral and eight homeless boys at Candelária Church, Rio de Janeiro, both in 1993, and of nineteen landless workers in the municipality of Eldorado dos Carajás, Pará, in 1996; or the murder of eleven people in Ponto de Encontro, a bar in Francisco Morato, São Paulo, in 1998. These events standardize, via photojournalism, a peculiar type of painful corporeal iconography, highlighting the dissemination of violence, the bloody aspect of contemporary Brazilian history.

In this refiguration in pieces, in agony, of characters, portraits, and narrators in recent Brazilian cultural production, there seems to be a combination of dialog with the corporeal fragmentation characteristic of modern art and one of its pastiches, the Guignol; with the tortures, executions, banishments, and political experience of the 1970s; and the increase of violent crime, including that committed by public security forces in Brazil during the 80 s and 90 s. However, attention must be paid to the fact that, in these attempts at bloody identification of fictional subjects, the exposure of these subjects is not anchored to subjective idealizations or to cohesive corporeal images, and that the very process of figuration and subjectivization involves a kind of nondisposable awareness of instability, an obligatory concomitant impulse for disfiguration, for the Guignol.

It is, however, an ambivalent disfiguration. Sometimes it points at victimization, but other times it masks of the agents of violence are superimposed on characters, narrators, and subjects, often maintaining equally a kind of hybrid register where a combination of victim and persecutor is what moves the literary subjectivization process. Hence, also, the proliferation of hybrid types, aberrations, figures which are self-defined as monsters in recent Brazilian literature. And which, in direct dialog with a particularly bloody context, 
by way of monstrous form, point to an epistemological gap, a classificatory destabilization, a confrontation in the cultural practice itself, with its limits of expressiveness and identification mechanisms, tried out before the affirmation of new forms of organizing social differences in cities based simultaneously on a globalizing homogeneity of space and an exacerbation of the panic of social heterogeneity, in the emergence of autonomous fortified citadels, in the expansion of violent criminality and the continuous violation of citizenship rights-precisely within the context of the political redemocratization process which is in motion in the country. In the midst of this motion, it is by means of victimization and protean aberrant forms that it seems possible to engender fictional portraits, literary subjectivity, shapeless representations of differences, hybrid cultural bodies closely related to an historical process of redefinition of identities and of ways of managing the social aspect.

This does not mean that the monstrous forms and animalizations of contemporary fiction are univocal. We must note, in this sense, the differences between the hybrid adolescent on one hand-arms too long, ostrich legs, hair all wrong-in the short story "Pequeno Monstro"("Little Monster") by Caio Fernando Abreu, where two liminals are superimposed on this "small, small monster nobody wants"-puberty and the discovery of homosexuality; and, on the other hand, the self-cannibalizing ritual performed by a woman in "Canibal" ("Cannibal"), a short story by Moacyr Scliar in which we see the character forced into the ritual because her rich "foster sister" refuses to share her big food container, in a particularly cruel figuration of the social divisions in the midst of apparent economic prosperity.

What seems to be at stake, however, in these recent fictional anomalies and zoologies is a disquieting closeness, not in the least exotic, of those animals and monstrosities. Such is the case in the purposely invisible "aberrations" of Bernardo Carvalho; or in the short story "Mandri" ("Mandrill") by Zulmira Ribeiro Tavares, the proximity of the zoo housing the animal to a Sunday in a room with the television tuned in to a talent show; or, in a seemingly inverse motion, as in Decálogo da Classe Média (The Decalogue of the Middle Class) by Sebastião Nunes, with the horrendous symbolizations of the middle class ("unlikely cross between cicadas and ants"), the proliferation of genital organs, lizards, diverse insects, skulls full of mice, chameleons, dogs, pigs, tricephalic bodies, but always in the midst of the most habitual activities, like weddings, business meetings, parties, sports; or, in Nelson de Oliveira's short stories, full of "animals from the strangest places," "imprisoned creatures," haunted figures, people "moving against their own feet," sleepwalkers, cannibals, "primitivemannered and malformed" people, "more beast than man," monsters 
at times hideous which, however, devote themselves to the most trivial of things-telephone calls, checks, accounting, everyday things. These are sorts of a particularly perverse hybridization between everyday life and the bestial, between perversity and victimization, paralysis and annihilation. Hence the figure of the invincible dragon, which is able to turn into whomever, dissolving any possibility of self-identification, of differentiation, in the short story "Não sei bem o quê, aqui" ("I Don't Really Know What, Here"). Hence the impossibility of self-recognition for the "little girl Victor" in the beautiful short story "A Visão Vermelha" ("The Red Vision"), from the book Naquela época tínhamos um gato (We had a cat in those times). Hence the disappearance, piece by piece, of Mr. McPiffs's body, another of Nélson de Oliveira's characters, similar to Angelina, the "slender and dark" creature "with big scared eyes" who devours herself in the short story "Canibal" ("Cannibal") by Moacyr Scliar. The actual boundary of the monstrous is destabilized for the laconic refiguration of G.H's "We are not human" in Clarice's Lispector's novel A Paixão Segundo G.H. (The Passion According to $\mathrm{GH}$ ).

\section{Sebastião Uchoa Leite, the Indetermination of Identity and the Noises of the Polis}

From the point of view of contemporary Brazilian poetic production, animalized, hybrid, anti-physical refigurations of the self, ambivalent or negative unfoldings of the subject, would function as a reinforcement of the anti-lyrical perspectives, as dramatizations of identity, as broken conciliation between voice and figure, and would play a particularly crucial role in works such as Sebastião Uchoa Leite's, for example. Here the subjective alter-representations, "entanglements of the self," "bifid tongues," fictions of the self, are composed of nuclear aspects of methodical negativity. Negativity that, above all in his most recent books and in an evident dialog with biographical circumstances, involves an agonizing, reiterated exposure of the subject, often found in a hospital environment, such as the section "Animal Máquina"("Machine Animal") in A Uma Incógnita (The Incognito One), or the ten texts that form the section "Uncertainties" in Fiction Life, and poems such as "Agulha" ("The Needle") or "Uma Voz de Subsolo" ("A Voice from the Underground"), from A Espreita (Lookout). But also a negativity that has in this agonizing subject only one of the many "fictions of the self"-"Here am I: all-the-selves/ self-scatological/ selfcryptic/ self-end"-on which Sebastião Uchoa Leite worked. These "fictions of the self" range from serpents, "monster/ wound around syllepsis," to vampires-Dracula, Nosferatu-from detective heroes to replicants and various murderers, from "Mr. Leite" to "a cornered joão cabral/ or a laughable valéry," from Bogart, Robert Walker, Yves Montand, Delon, Montgomery Clift, to "cockroach without feelers," "bat 
from the bar," from "doubly metamorphosed monsters" to "residue from sweeping/ that is collected/ with a dustpan." Disguises, concealment, and exchanged identities frequently convert poems into police micro-narratives where the central element is here a climate of general suspicion and there a kind of persecution of identity-of the subject, of the poetic element "on the edge of a cliff." In this sense, it is no coincidence that in Jogos e Enganos (Games and Mistakes), one of Uchoa Leite's collections of essays, the poet has devoted himself to the study of the "metaphor of persecution," of the structure and fundamental repertoire of variations on the persecution theme in modern and contemporary cinematography. This functions as an exercise in self-reflection, bringing to mind the scenes in shadow, the preference for slants and sinuosity, the disguises and inversion of roles that are the types of persecution dominant in his poetry.

At times, it is the perspective of the "fleeing persecuted" that dominates, as in "Vida é arte paranóica" ("Life is Paranoiac Art"): "simply run/ soul of replicant/ until they hit the plexus/ perplex target." At other times, it is the voice of a persecutor, of a spy-poet or a vampire with "spiky nails/ pointed teeth." Then again, it is the poetry itself that is persecuted: "We need/ radar/ and sonar intelligence/ to pick up shapes." Still other times, in a third-person distanced perspective, it is the subject of the poem himself that is sought: "The non-hero searches for his negative:/ his inner jack-the-ripper/ that would not want/ only to kill. / But also much more:/ to see the entrails hanging out." Frequently, however, as Sebastião Uchoa Leite points out in "A Metáfora da Perseguição" ("The Metaphor of Persecution"), "what seems to be perfectly marked territory-on the one side, the persecutor, and on the other the persecuted; on the one side, reason and on the other non-reason-is never so in an absolute way" [4], is also represented in "Os Assassinos e as Vítimas" ("The Murderers and the Victims"), a poem where murderers, detectives and persecutors of all types go through an inversion of roles and are persecuted by their victims or by the objects they chase.

Besides the exchange of roles, however, a poetic method is forged, itself based on an ambivalent perspective-that of "lookout," which suggests as much the need for a hiding place as it does a possible strike; as much the expectation of suffering an attack as the perpetration of a condemnable action. "(... There am I/ still as though I were another/ hired to commit a crime...)," we read in "Another One" ("Um Outro"). "(He, in general/ prefers to slip/ into a corner/ static/ as a viper/ before the strike/ he observes/ silently/ the passing of time/ controlled by the clocks/ he leafs through the pages/ of the half-open book/ the humid index of fear)," in another poem from 1997. Notice that in both cases the texts are, not by chance, limited by 
parentheses, in a mixture of concealment and suspension, a kind of graphic characterization of the lookout. In both poems we anticipate potential violence of which the subject could be the agent as well as the victim.

In the poetry of Sebastião Uchoa Leite, however, the indeterminacy of identity is not limited to those representations of the subject, but equally spread over the relationship between the images of the self and those of space. Not for nothing does he point to a mutual aquatic dissolution of subject and landscape in the series of poems on rain in the book A Espreita (The Lookout). "Andando na Chuva: São José" ("Walking in the Rain: São José") is a good example: "My selfdissolving/ water-self/ hair/ body hair/ eyes/ all pores/ letting go". Or it reveals-see "Numa incerta noite" ("On an Uncertain Night")-a two-way contemplation, "inverted vertigo," between the passer-by, "looking at the canopies of the trees," and the leaves and canopies, whose "cyclopic vegetable eye" watches him while he crosses the streets. And neither is it by chance that his poetry points out the loss of limits between inside and outside, observer and urban landscape, as in "Inside/outside: Rio de Janeiro," where the "stony street/ with hurrying/ pedestrians" seen "there, outside," "through the glass," seems to slide "into the glass," to come "from the other side of the table." One of the most characteristic masks of the poetic subject, that of the serpent, is even attributed to the landscape of Rio. The serpent is transferred to Guanabara Bay in "O grande brilho" ("The Great Sheen"), a 1991 poem: "Infused in the sea of yellows/ The green/ red spots/ Of the serpent-bay."

And, as opposed to the ethnographic and classificatory territorialization usually employed in the neo-documentary fiction of the 1990s, the production of a transitional zone between inside and outside, poet and landscape, in Sebastião Uchoa Leite's poetry, seems to reduce hierarchic distances of observation between subject and urban matter (particularly as the roles of observer and observed may always be inverted in his work). There are no moves towards cataloguing urban characters, the excluded, the homeless, criminals, as in "reporting" literature, in the near-photographic prose of recent decades.

If Sebastião Uchoa Leite's urban portrayals are populated with "unbeings," passers-by "under blue plastic tents," specimens of "squatting mankind," "static/ homeless/ facing the vile crowd," the poetic perspective-always marked by a deaf violence-is not hierarchic or systemic: it is oblique. Or, as is explained in "Exibicionistas e Voyeurs" ("Exhibitionists and Voyeurs"), a poem from Fiction Life, "Voyeurs look askance." In this case, we could also add that they sometimes 
exchange roles. This happens in two "jotted down" poems from Fiction Life. In one of them, "O Sobrevivente" ("The Survivor"), a subject watches "a mad woman" who "loudly debates Hamlet/ with herself" and registers with personal pronouns the overlapping of observer and observed: "That 'being over there'/ amusing himself greatly/ With my sound mind." In the other "jotting," "A Obra Lírica" ("The Lyrical Work"), poem and feces are literally superposed, for the said "work" results from urban litter, from a character in a squatting position defecating right in the middle of Azevedo Coutinho street, in Rio de Janeiro.

Even though Sebastião Uchoa Leite regularly works with police storylines and recognizable narrative plots, it is partly through this constant possibility of crossing identity, social, and spatial boundaries that an uneasy feeling is intensified in a reader exposed to liminal, ambiguous, discontinuous zones which unfold even in the most common, everyday environments and among immediately recognizable signs of urban landscape. Such is the case of Rio de Janeiro, the statue of Christ, the tunnel that links Botafogo to Copacabana, and Presidente Vargas Avenue. It is a movement towards destabilization and deterritorialization, uncomfortable from the point of view of poetical acceptance, which-assuming its direct relationship with the emergence of new urban practices, with the intensification of the asymmetric segregation of social space and of the generalization of violence and daily uncivil acts-does not limit itself to the inventory of Brazilian urban experience. Rather, such experience becomes a fundamental element of structural indeterminacy and negativity, of a difficult process of literary formalization which, in Sebastião Uchoa Leite's work, takes advantage of the clichés of criminalization and destabilizes them into unusual acts of confrontation and solidarity between the subject and the "noises of the polis," thus converting the modern topos of walks around the city, and their implicit plots, into real antilyrical figures with a self-corroding narrative based on a construction made from syntactic and imagined cuts, from "non-localities," and from a "hyper-realistic game/ between the self and the margin."

If, in the poetry of Sebastião Uchoa Leite, deterritorialization of the urban landscape overlaps a series of identity exchanges and disfigurations, one would have distinct poetic results, the expedient in a similar procedure by Ítalo Moriconi, in whose book Quase Sertão [5] (Almost Sertão), a hybrid spatial figuration is formed-a city-desert; or by Angela Melim, whose poetry is marked by the recurrent problematization of the horizon; or by Duda Machado, in whose poems space is depicted as drifting, as an escape from formalization. This is to name but three significant examples of a movement of 
indeterminacy in urban figuration in contemporary Brazilian poetry. We could also add to this movement the window that is closed to the sight of the seascape "in such a way as to banish, to veil the unfurled/ seafaring afternoon," from the poem "Proscrição" ("Proscription") by Lu Menezes, the mist in which the bay is portrayed in "Enseada" ("Bay") by the same author; what is almost a sidewalk inscribed on the body-"imperceptible/ trail of gadfly"-in one of the poems from Fábrica (Factory) by Fabiano Calixto, the horizon "out of all perspective," the recurrence of the desert image, and a self-figuration of the subject as a cactus in Solo by Ronald Polito.

If, strictly speaking, what stands out is mostly spatial destabilization, these deterritorializations are not lacking in bloody components: the "party suffering" referred to in one of Lu Menezes's poems, the "armored" body of Ronald Polito, the "sensation of heavy lead," the "stainless foot" of the factory worker, and the "fallen body" and "coagulated landscape" in Fabiano Calixto's book. In Sebastião Uchoa Leite's work we find the mass thefts/ megalopic slaughters/ infanticides," the "man shot dead," or the "Dantesque hell of the poor." Other examples are the "breath of hard mortality" in Almost Sertão, the "clothes line traversing the throat/ the comfort/ blunt dagger blade cutting the sky/ privation/ in the wire of the hanger" in the poem "Crente" ("Believer") by Angela Melim; the "wish to escape" in "Giro" ("Whirl") by Duda Machado, or the "battle/ fought/ somewhere," and the "I don't know late at night/ if I'm hurt/ if my body/ is streaked/ with bruises" in the poem "Mau Despertar" ("Bad Awakening") by Ferreira Gullar; and finally "I am poor, poor, poor," "it differs and hurts, hurts"[6] from "Vers de circonstance" by Carlito Azevedo.

The signs of violence in these figurations of the urban make reference, of course, to the increase in violent crime and the equally violent responses to it, to the generalization of a feeling of risk and potential conflict and to the loss of collective feeling in everyday big city life in Brazil. These issues have stimulated an equally increasing number of studies in the field of social science in the country. At times, they have the advantage of tension between political redemocratization and expansion of bloody crimes, which doubled, according to Angelina Peralva, "between 1980 and 1997." In her point of view, these signs are the result of insecurity amplified by the "interpenetration of the universe of the slums and that of the middle class," by "authoritarian continuity," and by the restructuring of the relationships which were dominant until the end of the military dictatorship "between State, political system, nation and society" [7]. On the other hand, in City of Walls, Teresa Pires do Rio Caldeira points out that this contradiction "between the expansion of the political citizenship and the delegitimization of civil citizenship" and the "disjunctive character of 
Brazilian democracy" are nuclear elements of a segregationist urban experience, relating violent criminality not only to the transformation of the "traditional configurations of power" but also to the "delegitimization of the judiciary system as mediator of conflicts," to the "privatization of the processes of revenge," and to the "legalization of forms of abuse and violation of rights" [8]. Or they can be related, as Luiz Eduardo Soares emphasizes, to the constitutive duplicity of Brazilian social organization-a society guided by elements of a "hierarchic cultural model" and "socialized according to a cultural model which is characteristic of liberal, egalitarian individualism." The duplicity of a "liberal-democratic process" in the context of a "strong national tradition both authoritarian and excluding" [9]. For when "the patterns of political exclusion are intense and most of the population does not acknowledge itself as participant of a collective journey," as Maria Alice Rezende de Carvalho puts it, "the city becomes the object of private appropriation, of predatory practices and of rapine, a place where social resentment and distrust prosper" [10].

Thus, the perception of the city and of its literary figurations as defined spatial units, as common spaces of socialization, becomes

problematic. Sometimes this perception expands into "sudden spaces," as in "Neste fio" ("In this wire") by Régis Bonvicino; at other times it undergoes intense understanding, as in the "four close walls," in the "compact, null/ cocoon," in the "sparse space" suggested in the book Solo by Ronald Polito. Sometimes the urban unfolds into desert, as is the case in Ítalo Moriconi's "almost sertão," or in the "desert city" mentioned in Duda Machado's "Whirl." Sometimes this perception takes advantage of the "in-between spaces," the transition zones, as in Angela Melim's work. Nevertheless, in the case of this literary deterritorialization, it is not only the urban form that is the order of the day (pauta) but also an internal process of formalization set in motion by contradictory guidance. Thus, the spatial indetermination, the formless geography, points in the direction of the exposure of a formal experience marked by the exacerbation of the tensions between horizon and drift, figuration and destabilization, persistence, and dissipation.

\section{IV. Ítalo Moriconi and the City as Sertão}

The mere superposition of the title Almost Sertão with the photograph of a clearly urban landscape on the jacket of the 1996 compilation of poems by Ítalo Moriconi already indicates, through nomination, the dominance of an urban visual, albeit exposed from one of its potential opposites. However, the protean movement, the real condensation of the two images, does not come into effect-thus the adverb "almost," which is responsible for the persistence of the two geographical 
references and the disparity evoked by them, and for this conjugation of city and sertão, accumulation and desert. The structural images of the book then point simultaneously to a common environment and to the impossibility of metaphoric conciliation. The difference and latent conflict between them thus suggests a methodical amorphia, a deliberate limit-"word that is missing," "half-words"-within this reversed figuration of the urban.

It is evident that, in this case, the images of the desert -the silence, the rough, the "odd vegetation, full of splinters" in the midst of the drift, the streets, "carnivals," a "faceless crowd," a "rain of shapes," "arms," "hips," "delayed cars," "unlit buildings," "sidewalks," and a succession of anonymous love chases, "scratching in the asphalt"-lend the evocation of the "sertão" the possibility of exposing the homoerotic paths of the city (the other city inserted into the regular city, into Rio Branco Avenue, into Copacabana, into the beach, into the everyday street corners), as well as the possibility of recurrent tension between the most intimate and the most public, the sertão "further inside" and the "excessively urban." There is a tension between the ganglions imploding in the neck and the McDonald's restaurant in (Notícias da AIDS) (News of AIDS), "between a street corner and old anguishes" in "Noturno" ("Nocturnal"), between "my space," "my insoluble look," subjectivity, and a series of transitory anonymous forms-"sharp curves," "surfaces," "cliffs," "vacant places"-or between the city as described as the hollow of the night and the hollows of the male bodies haunting the erotic imagination in "Noturno" ("Nocturnal"). This is also accompanied by class tension between "the mature man and the street boy," between the educated references spread throughout the poems and the object of the love chase, defined as "simple people." There is also tension between a spatiality marked by the accumulation of "so many bodies," of streets, buildings, corners, and the reiteration of images of a "rural scheme," of the desert, "imaginary plantain tree," "a limitless void."

The reference to the sertão in the poems of Ítalo Moriconi is not limited, however, to the trace of a homoerotic urban experience. It also seems to indicate dualities that persist in Brazilian literary life, oppositions and mediations between cosmopolitanism and the local datum element, between universalization and themes of regional, coastal, and interior character. This duality is latent, in a somewhat ironic way, in the city that is read as rural, and in the sertão, entangled with urban forms; the sertão, a paradigmatic image of "brazility," of a geography of open skies, with inclement light and usually peopled by cangaceiros and survivors, but which is converted into the emptiness of the night, the privileged landscape of the solitary love drift in Almost Sertão. Spatial duality serves as a structuring principle to, for 
example, "Brinde" ("Toast"), a poem in the form of a dialog with the "Dead Ox" by Manuel Bandeira where images of the sertão-desert ("there is no Nile, plain or desert, only/ extension as a trace of the silence that flows") and a possibly defined spatial configuration are opposed, while an enumerative drift ("dragging in the dark/ chains, martyrdom, rotten logs, / mirrors and broken glass and the rest") contrasts with a "blind nostalgia/ on the open sea, unknown, abandoned sea of the corners."

If the sertão is already seen simultaneously as vastness, desert, wide horizon, and as marked by sudden vegetable entanglements (rough, rare, intricate shapes, cacti, scrub, thus suggesting a certain potential figurative conflict), then it is not strange that it has served as reference, in the poetry of Ítalo Moriconi, to the exposure of opposed, conflicting images, not only of the urban landscape but also of the poetic form and the very process of writing. For it is by means of a split image ("All is conflict of figure in the garden of powers of the sarcastic street") which is, on the one hand, an abstract figure-desire of "pure, undivided form," "the form, the form of the forms, the desert"and, on the other, "dislocated by fits, stars," "rain of figures," city. These spatial figurations are defined in Almost Sertão as an internal disjunction, both of the urban experience and of the poetic form.

This image conflict, related to the historical experience and the conditions of literary production in contemporary Brazil, involves, in the poetry of Angela Melim, both the unfolding and disfiguration of the horizon and a methodical emphasis on the indetermination of the figured space above all. In Duda Machado's work, such image conflict also overlaps drift and form, constructive desire and dissipation.

\section{Angela Melim and the Dramatization of the Horizon}

The reproduction of the covers of all of Angela Machado's previous books in the collection Mais Dia Menos Dia (Sooner or Later) functions as a dividing mark, as a way of dating and singularizing the different sections of the volume. On the same token, the illustrations on the covers, if carefully observed, highlight one of the privileged images of her poetry - that of the horizon. An irregular horizontal line crosses the bottom of the cover of $O$ Vidro O Nome (The Glass The Name) (1974); a straight cut separates in two the title Das Tripas Coração Taking Heart / Displaying Guts (1978); the female body lying down seems to duplicate the outline of the background mountains in the illustration on the cover of As Mulheres Gostan Muito (Women love it) (1979); the title in miniscule, almost imperceptible letters is displayed horizontally on a deliberate emptiness of representation in Vale o Escrito (What Counts Is What Is Written Down) (1981); the 
boats loose on the water merely suggest a possible limit that can almost be mistaken for the top cut of the thicker paper of the cover in Os Caminhos do Conhecer (The Paths of Knowledge) (1981); the empty space, further on, at which a female figure seems to point, in Poemas (Poems) (1987); finally, Nelson Augusto's illustration in Mais Dia Menos Dia (Sooner or Later) (1996), where two lines and a little dark spot evoke the relationship between subject and landscape, poetical experience and thematization of the horizon and, through a limit line, delimit in space the duration and image of a time to come, which is suggested in the potential, almost near future of the title.

"I'm looking for the right word/ for the superposed parts of two spheres/ Intersection?/ And loneliness:" the quest expressed in "Rabo de Galo" ("Cock's Tail") in the 1996 book underlines Angela Melim's concern with the limiting, transitional spaces, the "rare clamps," the inbetween spaces, the half-way, the horizons. And there is indeed a vast succession of seas and skies in her poetry. The water that "shines tranquilly at midday," "deep blues versus high seas," "torn blues/ huge/ clear landscapes," "an occasional purple coconut tree against the pink sky," "the lines of shimmering water and the blue, somewhat foggy mountains." In the case of Angela Melim, this succession of atmospheric and maritime horizons which, with a tendency to the unlimited, to mirroring the "states of the soul," and seeming to reproduce a romantic-picturesque version of the landscape of Rio de Janeiro, point in another direction.

They function, at once, as a way of cutting out the presence of the world-even when, at times, they function as a backdrop ("green/ mined/ field," "mountain of cadaver," "violated ear, ruptured tympanum/ arms cut off/ heads")—-while they also function as a constitutive element of the poetic experience. Thus, there is a tension, via landscape, of the self-referent, expressive model dominant in Brazilian poetic production of the 1970s, of which Angela Melim's first books are coetaneous. And, as is suggested in the text of "Minha Terra" ("My Land"), marked by an image in negative of the land "roots in the air"-and of the "going back home" theme, of taking root "Nothing is natal"-it is about a landscape in direct contrast to descriptiveness in the romantic mold, a descriptiveness which would leave traces in subsequent Brazilian literature. In the poetry of Angela Melim, the fixedness of the target point is frequently eliminated so that diverse forms for objectifying and lyrical distancing are exercised, as in "Assim uma Linha Verde da Janela - Um dia" ("Thus a Green Line of the Window - One Day"): "Thus a green line of the window-one day/ instant, sudden/ running/ parallel to what is fast/ hill/ plain/ thin metal stiletto/ in the background." The "thin stiletto" is discreet, almost imperceptible, serving a similar function to the "mined/ field" of the 
poem "Fogos Juninos" ("Fireworks of June"), in terms of the bloody unfolding of something similar to a mere descriptive picture.

Likewise, contrastive unfoldings of the poetic voice are also attempted. For example, in the casualness of the subject that gives information to the traveler in "Roteiro" ("Travel Plan") and the systematic interruption of his speech by descriptive, impersonal, and greatly detailed parentheses-where duplicity also attains the figurations of space. Hence the transformations-from diaphanousness, gauze, cloud, to the silly cheap pink - that the very idea of a pink sky should go through in "No Céu Cor-de-Rosa" ("In the Pink Sky"), or the mobile, suspended definition of the landscape contained in "A Duna vira Nuvem, se quiser" ("The Dune Becomes Cloud, if It Likes").

It is not, then, as extension, infinity open to the gaze, or as fixed, outlined limit that the image of the horizon seems to guide Angela Melim's poetic writing. Rather, it is, above all, as in-between space, as dislocation zone, as "exploration of blind spots, of the margins of indetermination in language and in landscape," [11] as Michel Collot puts it in L'Horizon_Fabuleux, which she thematizes and transports to the poetic space, the notion of the horizon. This, from the point of view of the graphic-syntactic organization of the poem, explains the number of structural blanks, intervals, parentheses, and dashes in her texts. It also explains the marked taste for the isolated, loose verse that goes through the page, cutting or closing some of the poems like a divider, like an internal line of the horizon, and many times intensifying the unfolding or liminal conflict. For example, the long sentence in "OMar não Existe" ("The Sea Doesn't Exist") that, after five short verses, internalizes a sea of absence and impossibility in a sort of organic horizon in a state of corrosion: "Acidity is a fire that eats the dark pipe that runs throughout the body." Also, the verse in "Ronca um motor" ("An Engine Roars") from Sooner or Later, that says, "It is summer opening up." Separated from the other verses by two blank spaces, this verse seems to synthesize, by means of graphic highlight, the previous images of the boat, the sea, and the heat. At the same time, it also appears to represent a temporal-landscape extension "in open skies." Yet, another horizon accompanies it, one which is conflicting and inverts not only its amplifying movement but also the temporal reference to a period that is beginning - the genesis of summer transforming itself into the image of a past that is close to dissolution: "Afternoon, ice-cream, love/ balcony/ in bowls of the past/ melting."

Instead of being a spatial/temporal foundation or point of guidance from the subjective perspective, the awareness of the horizon in the poetry of Angela Melim points, therefore, to a systematic motion of 
mutual re-dimensioning of subject and landscape, of which the reflection on death in "Lemon Brother" is a good example. That reflection is, in fact, the mere register of a fruit that falls and rolls on the ground "which now engulfs/ the open/ desperate flesh/ of the lemon." Another good example is her preference for intervals, for the lines that figure and disfigure the space and the writing, for a kind of dramatization of the horizon, unfolded into diverse, albeit obligatory, forms of conflict and indetermination.

"And she would like," we read in "Os Caminhos do Conhecer" ("The Paths of Knowledge"), "to paint her nails red. While she wrote the words in the notebook she would notice the fingers with shiny tips holding the ballpoint pen and feel conflicting pleasures." A similar movement occurs between a "there, inside" and a "jasmine tree" in "Mulheres" ("Women"), between an "on the surface" and a "deep pit" in "Faca na água" ("Knife in the water"), between "suspended crests/ stones of salt/ threads of sea" and "its faraway bottom/ anchor/ the sand beds and their spotlessly clean sheets" in "A Ship"-_windows," "lakes on the chest," "ship"-where borderline images, types of "nonplaces," are figured. To those images we could add the sheath, the clothesline, the sea front, the gaps, the edges, the empty space, the bars and the margin from so many others of her poems where these conflicting directions are tensioned and live with each other. These images, amidst a succession of seascapes and landscapes which at first sight are sparsely populated and almost "story less," activate a sort of deaf, almost imperceptible conflict between the natural picture and the historical horizon. Among a lyrical exercise around the sun, flowers, and loss in "Corajoso como a Beleza" ("Brave as Beauty"), with its succession of warlike images: shots, bullet, pain, roars, combat; among "the tiles/ the green dull chlorine/ the swimming pool" and the "wire" that preserves, in "álbum," ("Album"), the "smell of jasmine" and "live blood/ held with difficulty;" the "clear blue sky" and "grenades," "fire, smoke," in "Fireworks of June." And in "Trilha" ("Trail"), between the horizon of the city and that of the writing process, a third, warlike zone of "siege, casualties, barricade, weapons," mediates the other two and seems to set new dimensions, historically, to those horizons.

\section{Duda Machado and the Methodical Drift}

Duda Machado's poems, on the other hand, though equally marked by a conflictive exposure of space, seem to be moved by a counterorganizational principle, by a methodical indetermination of a more varied sort which unfolds and re-invents from within, indicating a purposely unstable poetic form-one of escape. This poetic form is, not by chance, figured repeatedly by images that are marked precisely 
by movement, transparency, and the tendency toward the formless, toward deterritorialization. The images of the wind and the wave are fundamental elements for the self-explicitness of poetic narrative that is based on modulation ("who reigns?/ a modulation/ capable of tuning/ understanding"), based on the tension between going off course and condensation, between drifting and a wish for settling down ("breeze/ just formed/ the confluence/ between passing-by and dwelling"). These elements dominate Margem de uma onda (Edge of a Wave) (1997), his latest book.

There is, however, since Zil, a recurrence of those aerial, aquatic, mobile images. The association of the book to the river is present in the initial text of this 1977 volume, in the "sea/ on the edge of the hulls" in "Verão" ("Summer"), in the "liquid, cascading, filling" vowels, in the images of cereus jamacaru [12] flying in "ária" ("Aria"), or in the poem/question about what would make a louder sound, "the flight or the singing of a bird." These images in motion also dominate his second book, Um Outro (Another One) (1990): several routes, targets in motion, the crowd defined as "windmills of arms," the rain that follows the young lady, a cyclist that passes by and the setting on wheels of even "fixed ideas" (an almost paradoxical example of the Aeolian, unstable poetic narrative of Duda Machado).

However, in Another One, winds, flights, and perpetual motion are contrasted with an exploration, also recurrent, of the margin, the horizon, the limit, the happening, the language. These elements also show a contrast between "contemplator, sky and sea," "sea and asphalt," "garden and evening," "death-life." Between a wish for contour, outline, formalization, and a sort of hesitation of forms, of inevitable dematerialization. "Life,/ without measure/ that meaning / severity," we read in the second poem in Another One. "The horizon," the first stanza of "Juntos" ("Together"), goes, "is the light/ that in such unanimous color/ extinguishes the surfaces/ which it lives on." Just as in "Tanto Ser" ("So Much Being") where, in the cloudy internal mirror, "acts are disfigured" and the body is shown as "impalpable, carcass/ that the spirit cannot find."

In Edge of a Wave, this tension between formalization and dissipation, figuration and imminent disfiguration, thematized differently throughout the whole the book, gives way to the singular poetic narrative as exposed in "Fable of the Wind and the Form," "Swimming Pool Morning" and "Edge of a wave"-which is partly connected to "Imitation of Water" by João Cabral de Melo Neto. An analogy is established, through denial at first, between the wind and the form, incompatible elements in a state of undiminishing disagreement because, on the one hand, of the desire for persistence which is 
characteristic of the form and, on the other hand, of the fleeting aspect which is characteristic of the wind. In both cases, however, the diverse routes signal a correspondence, in reverse, between these differences, which lead to mutual self-denial (with the form, through the activation of a process of multiple unfolding in metamorphosis, and with the wind, due to the possibility that it can suddenly take a form, supposing its movement strikes, for example, "an Aeolian harp/ or Calder's mobiles," as the poem's two last verses emphasize).

In the case of this fable, the curious fact lies not only in the "unison disagreement" on which it is based, but also on the very fact that the two images necessarily lead towards their own demise, as is the case with the voice that "withdraws" in "Interferência" ("Interference"), with the color that "falls on itself" in "Aventura da Cor" ("Adventure of the Color"), with the details that are "shaped by desegregation" in "Poética do Desastre" ("Poetry of Disaster"), with the "fatigue" that "to each thing/ unfolds and dissipates" in "Dentro do Espelho" ("Inside the Mirror"), or with the bedroom that "after condensing/ time and space" focuses on the window and finds the emptiness and "the limits of the sidewalk/ below" in "Resumo Quasi Abstrato" ("Almost Abstract Summary"). In the midst of this succession of dissolution and the threat of self-annihilation which is built into the images that dominate so many of these poems, it is not strange that some of them are converted, on the contrary, into genealogies of form, such as "Traço e Movimento" ("Line and Movement"), "Fragmentos para Novalis" ("Fragments for Novalis"), "Condição" ("Condition"), or "À Noite na Estrada" ("On the Road at Night"). Neither is it strange that form and drift are presented in an explicitly geminated way in the poem "Trevo" ("Clover"): "an image in drift/ so dense/ in its self-absorption/ that it excites/ the desire for form/ until it dies away/ and its drift is reaffirmed/ eight octaves higher."

A fundamental element of Duda Machado's poetic method, it is not merely a reflection on indetermination, but rather a composition process which is in itself-and not only in its images-internally tensioned by structural negativity and resistance to formal unification. Internal tensioning is manifested both by means of an expedient that is recurrent in enumeration-exemplified by his two "Almanaques" ("Almanacs"), in contradictory images ("and at $40^{\circ} \mathrm{C}$ a wintry unhappiness"), and by means of sudden cuts in the poem: another voice (as in the third stanza of "Fala" ("Speech") or in the middle of "Corte e Costura" ("Sewing"); dots (as in "Album"); an interval as in "Psiu" ("Hey"), and the rest of "Fantasma Camarada" ("Friendly Ghost"); an exchange of register (as in the impersonality of the first six stanzas and the intimacy of the last two verses of "Oração com 
Objetos" ("Sentence with Objects"); a question (as in the verses in brackets of "Edge of a wave").

Tensioning is equally manifested, in the poetry of Duda Machado, through the irruption of extremely concrete, almost brutal images among aerial figures and formal dissipations: the beggar in "Flores de Flamboyant" ("Flamboyant Flowers"); the scenes showing persecution, searching and execution in "Fim de Semana" ("Weekend"); the bus passengers converted into indistinct hybrid beings in "Carapicuíba," the egg-laying and the carrion children in "Urubu-Abaixo"("Vulture Below"). This spatial figuration is represented by the poet himself in "Devoração da Paisagem" ("Devouring the Landscape"). In this poem, an appropriately tranquilizing first stanza, with a simple description of a view-houses, hills, trees, road, and brook-is followed by three deterritorializations: the first in the sense of an expansion-"colors that surpass distances," "the look that wanders and remains/ in search of its home;" the second in the sense of an unfolding of the target, a contraction in the landscape- "from somewhere,/ away from the retinas/ the beast bursts forth;" the third showing the imprisoned landscape, relating its devouring. At the same time there is the suggestion of a sort of historical and formal impossibility of the landscape and of bloodless spatial figurations. Hence the frayed superposition-"almost"-of sertão and city in the poetry of ítalo Moriconi, the conflicting unfolding of horizons in Sooner or Later by Angela Melim, Sebastião Uchoa Leite's indeterminations of identity, and the counter-formalization converted into active principle of composition in Duda Machado's work. These are distinct exercises of deterritorialization and spatial non-representability which, through denial and conflict, seem to contribute, on the contrary, to the intensification of the perception of the present moment, as they amplify formal investigation itself when poetic practice intersects with the recent historical unfolding of an urban experience as violent, segregating, and authoritarian, such as that of Brazil.

\section{Notes}

1 Xavier, Ismail. "O cinema brasileiro dos anos 90" (entrevista). IN: Praga. Estudos Marxistas no. 9. São Paulo, Hucitec, 2000, p. 110111; p. 116-117. See also Mário Sérgio Conti. "Encontros Inesperados" (Entrevista com Ismail Xavier). IN: Mais!. Folha de S. Paulo Dec. 3, 2000. p. 8-9.

2 Caldeira, Teresa Pires do Rio. Cidade de Muros. Crime, Segregação e Cidadania em São Paulo. São Paulo, Editora 34/ EDUSP, 2000. p. 9. 
3 ld. Ibid. p. 11.

4 Leite, Sebastião Uchoa. Jogos e enganos. Rio de Janeiro, Editora UFRJ; São Paulo: Editora 34, 1995. p. 140.

5 Sertão is a region of dry hills and scrub in Brazil's drought-ridden northeast.

6 In Portuguese this is a play on words "difere" = differs/ "fere" = hurts: "difere, fere, fere".

7 Peralva, Angelina. Violência e Democracia: o paradoxo brasileiro. São Paulo: Paz e Terra, 2000. p. 22, p. 59, p. 84, p. 89.

8 Caldeira, Teresa, op. cit. p. 343.

9 Soares, Luiz Eduardo. "Uma Interpretação do Brasil para contextualizar a violência". IN: Pereira, C. Alberto Messeder; Rondelli, Elizabeth; Shollhammer, Karl-Erik e Herschmann, Michael (org.). Linguagens da Violência. Rio de Janeiro: Rocco, 2000. p. 34-36.

10 Carvalho, Maria Alice Rezende de. "Violência no Rio de Janeiro: uma reflexão política". IN: Pereira et alii (org.). Linguagens da Violência. p. 56.

11 Collot, Michel. L' Horizon Fabuleux II. XX e Siècle. Paris: Librairie José Corti, 1988. p. 17.

12 In Portuguese, mandacaru, a characteristic plant of the sertão.

\section{Works cited}

Abreu, Caio Fernando. Os dragões não conhecem o paraíso. São Paulo, Companhia das Letras, 1988.

---. Ovelhas negras. Porto alegre: Sulina, 1996.

Azevedo, Carlito. Sob a noite física. Rio de Janeiro: Sette Letras, 1996.

Calixto, Fabiano. Fábrica. Santo André: Alpharrabio, 2000.

Carrero, Raimundo. As sombrias ruínas da alma. São Paulo: lluminuras, 1999. 
Carvalho, Bernardo. Aberração. São Paulo: Companhia das Letras, 1993.

Felinto, Marilene. Mulheres de Tijucopapo. 2nd ed. São Paulo: Editora 34, 1992.

Ferrez. Capão Pecado. São Paulo: Labor Texto Editorial, 2000.

Fonseca, Rubem. Contos reunidos. São Paulo: Companhia das Letras, 1994.

---. O buraco na parede. São Paulo: Companhia das Letras, 1995.

Freire, Marcelino. Angu de Sangue. São Paulo: Ateliê Editorial, 2000.

Inimigo Rumor. Revista de Poesia. no. 3. "Dossiê Ferreira Gullar". Set- Dez. 1997.

Leite, Sebastião Uchoa. Obra em Dobras. São Paulo: Duas Cidades, 1988.

---. A uma incógnita. São Paulo: lluminuras, 1991.

---. A Ficção Vida. São Paulo: Editora 34, 1993.

---. A Espreita. São Paulo: Perspectiva, 2000.

---. "A Metáfora da Perseguição." IN: Jogos e enganos. Rio de Janeiro/ Editora UFRJ; São Paulo/ Editora 34, 1995.

Lins, Paulo. Cidade de Deus. São Paulo: Companhia das Letras, 1997.

Machado, Duda. Margem de uma onda. São Paulo: Editora 34, 1997.

Melim, Angela. Mais dia menos dia. Rio de Janeiro: Sette Letras, 1996.

Melo, Patrícia. Acqua Toffana. São Paulo: Companhia das Letras, 1994.

Menezes, Lu. Abre-te, Rosebud!. Rio de Janeiro: Sette Letras, 1996.

Noll, João Gilberto. Romances e Contos reunidos. São Paulo:

Companhia das Letras, 1997.

Nunes, Sebastião. Decálogo da classe média. Sabará: Edições Dubolso, 1998. 
Oliveira, Nélson. Naquela época tínhamos um gato. São Paulo:

Companhia das Letras, 1998.

---. Treze. São Paulo: Ciência do acidente, 1999.

Ortiz, Esmeralda do Carmo. Por que não dancei. (org. Gilberto Dimenstein). São Paulo: Senac, 2000.

Polito, Ronald. Solo. Rio de Janeiro: Sette Letras, 1996.

Santiago, Silviano. Cheiro Forte. Rio de Janeiro: Rocco, 1993.

Scliar, Moacyr. Contos reunidos. São Paulo: Companhia das Letras, 1995.

Silva, Hélio R. S. e Milito, Cláudia. Vozes do Meio-Fio. Rio de Janeiro: Relume-Dumará, 1995.

Tavares, Zulmira Ribeiro. O Mandril. São Paulo: Brasiliense, 1991.

Varella, Drauzio. Estação Carandiru. São Paulo: Companhia das Letras, 1999.

Vários. Letras de Liberdade. São Paulo: Madras, 2000.

Xavier, Valêncio. "Minha história dele". IN: Ficções. Ano 1, no. 1. April 1998. 